\title{
BLOCKED TRANSITION AND POST-SOCIALIST TRANSFORMATION: SERBIA IN THE NINETIES
}

\author{
Silvano BOLCIC \\ University of Belgrade \\ Cika Ljubina 18-20, 11000 Belgrade, Serbia; e-mail: bolcic@yubc.net
}

\begin{abstract}
This paper is showing that Serbia in the nineties was an interesting case of post-socialist transformation in spite of the greatly blocked transition. The key sign of the post-socialist transformation has been the formation of a new transformative social force formation of entrepreneurs and of the strata of social owners. Initial transformation of ownership relations in Serbia began in the 1990-1991. period, with limited privatization of some $40 \%$ of all former "socially owned" enterprises . Privatization of such firms was practically blocked in 1992-2000. period. Some comments on ownership transformation after the regime change at the end of year 2000 are given in the paper.

There was an autonomous growth of the private sector during the nineties generated by the formation of some 200.000 new private firms. It was shown in the paper that some branches, like retail trade, have been de facto privatized thanks to the predominance in trade business of new private retail trade firms.

Social features of new entrepreneurs in Serbia have been analyzed, based on author' $s$ surveys. Positive impact of new entrepreneurs has been not only in generating and enforcing systemic changes by the end of nineties, but also in preventing overall aggravation of living conditions of people in Serbia in this period. New entrepreneurs were spreading new life orientations, innovativeness, readiness to take responsibility for one's life, especially among the young generations. The author believes that post-socialist transformation in the nineties facilitated regime change in the Fall of year 2000.
\end{abstract}

Keywords: Serbia, post-socialist transformation, transition, blocked transition, entrepreneur, new entrepreneurs, spontaneous privatization

In the literature on transition and post-socialist transformation in the nineties Serbia (as well as FR Yugoslavia) has been scarcely mentioned and analyzed. Many other aspects of dramatic and disturbing developments in Serbia (interethnic wars, in particular) had attracted attention by various audiences, but not developments related to the post-socialist transformation of Serbian society in this period. Transition in this country was considered as being blocked since 1990. Most social analysts think that transition in Serbia had begun to take place after the end of Milosevic's rule at the end of the year 2000 .

The aim of this paper is to put some additional light on the generally accepted assessment that transition has been blocked in Serbia in the nineties. It will be shown 
that, in spite of this blockade, there were some institutionally and non-institutionally generated activities in favor of privatization, which have contributed to the real post-socialist transformation of the Serbian society in the nineties. Specifically, this paper will describe the process of "ownership transformation" of the former "self-managed organizations" at the beginning of the nineties and pinpoint the activities in relation to privatization during the nineties.

The key sign of the post-socialist transformation has been the formation of a new important transformational social force in Serbian society, namely, the formation of entrepreneurs and of the strata of private owners. Based on the available survey data on social profile of entrepreneurs, some features of these "new entrepreneurs" will be analyzed and some comments about their impact on the transformation of Serbian society in that period will be made.

This author is convinced that, in spite of all tragic and destructive "developments" in Serbia in the nineties, Serbian society entered the New Millennium as a considerably changed society, with many features similar to other post-socialist societies. Also, it seems sound to claim that such real social transformations, which were going contrary to the regime intentions to prevent transition, have made the recent change of regime and the end of Milosevic's rule possible in Serbia.

\section{ON THE "BLOCKED TRANSITION" AND LIMITED PRIVATIZATION IN SERBIA IN THE 90S}

Those who speak about "blocked transition" in Serbia mean in the first place that there has been no comprehensive privatizations of the former state/ "social"/ firms. Yet, there has been an initial phase of "ownership transformation " in Serbia, initiated by several federal laws enacted in the 1989-90 period (Zec et al. 1994). The initial approach of the federal lawmakers at that time was to make employees in former "self-management" organizations as individual "shareholders" in their firms, to motivate them for a more efficient use of capital and all resources at their disposal. According to the available data (Zec et al. 1994: 228) by the end of 1992 some 33\% of "social" enterprises completed the process of ownership transformation ${ }^{1}$ and legally these organizations were functioning as "share-holding companies". However, only part of the formerly "socially owned capital" went nominally in the hands of employees. State banks and other "social firms" had their shares in such companies, and sometime, some outsiders, private owners, became shareholders. Part (1/3) of the assessed value of the formerly "socially owned means" has been transferred, by law, to the Development Fund, to be used for solving pressing social problems of the unemployed, retired people and for some other social needs. In those "transformed" firms some $43 \%$ of total values of former "socially owned capital" legally existed now as "capital of shareholders".

1 Laws, which were enacted during the rule of "socialists" were not titled as "laws on privatization", but as "laws on ownership transformation". The first law aimed at privatization to be named "law on privatization" has been the 2001 Law, prepared and enacted after the regime change in October 2000.

Review of Sociology 9 (2003) 
According to the available data, some additional $30 \%$ of all "social enterprises" have started some activities directed toward their "ownership transformation" in the period 1990-1992. Even though there are no reliable data on subsequent "transformational" activities in those non-transformed firms, from the data on firms pending for privatization in the "post-October 2000" period, one could assess that in the second half of the nineties there was no significant "ownership transformation" of the former "self-managed" firms in Serbia.

Former "public companies", controlled during the years of "self-management" more directly than other "social firms" by the state, (federal state, state of republic, city governments, or governments of specific municipalities), became (after 1989) public companies in the state property. These were firms in important businesses in energy production and distribution, public transportation, utilities, media, health, education. According to the available estimates (Zec et al. 1994: 241) some $44 \%$ of the assessed value of the formerly "socially owned capital" has become state property in this first phase of "ownership transformation".

In this short story about the initial attempts at privatization in Serbia it is necessary to stress that in the summer of 1994 the Serbian parliament enacted a so-called "Law on revaluation" of the sold "socially owned means" in the 1990-1994 period, with the idea to prevent unjust property gains by shareholders because of the effects of the inflation in this period, especially of the hyperinflation in 1992-1994. This measure of retroactive valuation of already transferred capital in the hands of individual shareholders resulted in a de facto return of the "privatized" capital of the "socially owned capital". According to the available estimates (Zec and Zivkovic 1997: 83) 97\% of the "privatized" capital has been renamed as "socially owned", and only $3 \%$ remained in the hands of shareholders.

In the second half of the nineties, especially in 1997, a new Law on ownership transformation was enacted by the Serbian parliament, with the idea to increase some incentives (in the form of free shares) to employees in the still non-transformed firms to start privatization. There were also more strict deadlines determined by the Law to end the process of "transformation". By the end of the year 2000, only a minor number of firms started transformation in shareholding companies in accordance with this Law of 1997. But, some 400 "social firms" had a speedy "ownership transformation" in the first half of the year 2001, when a new Law on privatization was in preparation. The new "law on privatization" in preparation was supposed to greatly abrogate the rights of employees on free shares provisioned by the former laws and to reduce the role of employees' collectives in the privatization process, and this seems to explain the speeded "ownership transformation" at the beginning of the year 2001.

The new government of Serbia enacted a new Law on privatization in the summer of 2001. Privatization became obligatory and should be completed during a period of four years after the Law had been enacted. The state agency for privatization has been directly preparing some 150 firms to be sold by tenders and some 7000 firms on auctions. By the end of 2001 three of 150 firms planned for tenders were sold, and 22

2 According to the Law on Enterprises, enacted in 1989, the former "self-managed organizations" were legally renamed as "social enterprises" if their assets were still "socially owned". 
auctions were successful. During the year 2002 some additional 10 firms were privatized by tenders and several hundreds of "social firms" were successfully privatized through auctions. ${ }^{3}$ The process of privatization is still slow, for many reasons, which could not be analyzed properly in this paper. ${ }^{4}$ Thus one could say that the real process of the institutionally provided privatization of the former "social firms" in Serbia has not gone too far, in spite of the described steps during this period to provide new "ownership arrangements" and a new system of governance in Serbian enterprises. Still, some important social transformations were under way.

\section{ON THE POST-SOCIALIST TRANSFORMATION OF SERBIA IN THE NINETIES}

In Serbia during the nineties its social structure, especially the political elite stratum remained basically closed (Sekelj 1998: 613). The rule of law was greatly a "lip service" of the rulers. Political pluralism became a nominal but not a real framework of the Serbian political life (Goati 1995), since the de facto political power was not in the parliament but in the hands of the President of Serbia (S. Milosevic) and his most loyal collaborators. Permanent ideological requests for the "country's unity" and the "priority of national interests" served well as a legitimization formula of a non-democratic, totalitarian rule of the Serbian regime in the nineties, and for the suppression of civil society in this country. Under such societal conditions in Serbia the post-socialist transformation and the spread of entrepreneurship should have been impossible. Was this the case?

In spite of many anti-transitional trends, there has been a gradually increasing share of the private sector in the formation of social product ${ }^{5}$ of Serbia (see Table 1). This was in part the result of limited privatizations of smaller former "socially owned firms" at the beginning of the nineties, even if many of the "transformed" former socially owned firms had in fact mixed state and social ownership and private ownership. The increased share of the private sector in the social product formation was, in part, the outcome of the rapid formation and growth of new (albeit small) private firms established primarily by individual domestic founders. Finally, this increase was a consequence of private ownership in agriculture, handicraft and services, which existed in the pre-transition period.

3 These are pieces of information given on the Web site of the Serbian Ministry for Privatization.

4 There are some current circumstances, like the great political instability in Serbia, preventing more comprehensive privatization, and also some processes of longer duration, like the overall destruction of the society which is generating a slow process of reconstruction of the basic societal institutions, including those regulating economic life of this country (more on the "destruction of society" of Serbia in the nineties, see Bolcic 1994).

5 "Social product" is a term used in Yugoslav official statistics and should be understood as "gross domestic (material) product", representing "the value of all final products in a period of one year distributed and spent for satisfying the direct, public needs, investment and reserves as well” (SGJ-01: 130).

Review of Sociology 9 (2003) 
Table 1. Social and private sector's social product (GDP)*, Yugoslavia**, 1989-1999

\begin{tabular}{lrrrr}
\hline & 1989 & \multicolumn{1}{c}{1991} & \multicolumn{1}{c}{1995} & $1999^{* * *}$ \\
\hline Total social product (GDP) & 49,811 & 33,807 & 14,155 & 20,045 \\
Private sector product (GDP) & 5,416 & 6,729 & 7,862 & 8,448 \\
\% of private social product & 11 & 20 & 55 & 42 \\
Indices of change (1989=100) & 100 & 68 & 28 & 40 \\
Total social product & 100 & 124 & 145 & 160 \\
Social product. Private sector & & &
\end{tabular}

* The numbers are millions of Yugoslav Dinars, in the 1994 "constant prices".

**Available data for Yugoslavia depict also trends for Serbia since the Serbian GDP is about 95\% of the Yugoslav GDP.

*** Excluding data for Kosovo.

Source: SGJ-98:124; SGJ-01: 91.

The share of the private sector's economy in Serbia is somewhat smaller when assessed by the share of the private sector's employment in the total employment in Serbia (see Table 2). It is evident that during the nineties the employment in the social sector declined at the much lower rate than the social product of the social sector in that period did. At the same time the social product of the private sector grew faster than the employment in that sector. These trends reflect two different business (and social) orientations of employers in these sectors. The "state rulers" as "employers" hesitated to fire employees extensively from social and state firms, which were in reality collapsing. There was fear of uncontrollable social unrests. Instead of firing employees, "state employers" subsidized social firms, in part through the virtually raised state incomes via hyperinflation. Salaries of those employed in social and state firms have been drastically reduced in their real purchasing power. Also, wages were paid very irregularly. During the 1991-1994 period around 40\% of employees in the social sector were sent (from several months to more than one year) on extended and "forced leave" (Bolcic 1995a), with minimal or even no payment. The state "generously" tolerated all forms of work in the "hidden" economy, and provided, often through the unions, some "payments in kind" (food and other "necessities") to pacify employees, especially those in larger industrial organizations. Constantly nourishing nationalist sentiments of the people served as a good "antidote" to expressed and suppressed dissatisfactions of the Serbian population, whose negative energy was mobilized against "enemies" (foreign and domestic) instead of the "rulers" which were de facto destroying the fundaments of a civilized life in Serbia. 
Table 2. Trends in total employment and employment in the private sector: Yugoslavia 1989-1999

\begin{tabular}{lrrrr}
\hline & 1989 & 1991 & 1995 & $1999^{*}$ \\
\hline Total employment (in 000) & 2791 & 2625 & 2379 & 2238 \\
Employment in social sector & 2733 & 2438 & 2114 & 1710 \\
Employment in private sector & 58 & 187 & 265 & 332 \\
\% of total employment in the private sector & 2 & 7 & 11 & 14 \\
Indices (1989=100) & & & & 63 \\
Social Sector & 100 & 89 & 457 & 555 \\
Private Sector & 100 & 332 & & 65 \\
\hline
\end{tabular}

* Excluding data for Kosovo.

Source: SGJ-98: 96; SGJ-01: 132.

Private employers hesitated to hire as many employees as a normal organization of their business would have required, because of fear for their business situation in the near future in the collapsing Serbian economy. Of course, cheap, unofficially engaged labor in the "grey" labor market provided considerable untaxed profits for many owners of private firms. The tacit coalition of the "ruling circle" and some new entrepreneurs contributed to such mal-developments of the rapidly vanishing social sector and to the insufficient growth of the private sector.

What pressingly demands an explanation is the reason for such a mal-development of Serbia in the nineties. Some analysts suggest causes of longer duration, like the missing democratic traditions in Serbia and the prevailing authoritarian value orientations of the majority of Serbs (Golubovic et al. 1995), where rulers tended to be dictators with a large popular support (Podunavac 1998: 30-36). This could explain also the practically uncontested populist rule of Milosevic in the nineties.

The multi-ethnic composition and suppressed ethnic conflicts in the former "socialist" Yugoslavia also seem to be very pertinent explanations of the Serbian case of the interrupted post-socialist transformations together with the subsequent revival of ethno-nationalism as a mobilizing force used by the former and new political elites to preserve or to enforce their dominant social position (Sekelj 1995). The masses were effectively controlled and pacified by nationalistic state policies, in spite of their great discontent caused by the unwise state policies of the "socialist-nationalist" rulers. But, one should separate the role of objective multi-ethnicity and of normal inter-ethnic tensions, which existed in all periods of the multi-ethnic state of Yugoslavia, from the destructive role of ethno-nationalistic mobilizations of people in Serbia, as well as in other post-Yugoslav societies in the nineties (Bolcic 1995b).

Here one must understand the conditions under which this "ethno-nationalistic counter-revolution", led by the former "socialist" rulers, became possible, in Serbia in particular. First, it might be relevant to analyze the power system in the former Yugoslavia, not only the distribution of social power, but also the sources of power of

Review of Sociology 9 (2003) 
the various social groups, especially the role of the military elite ${ }^{6}$ and the established "power culture" (Bolcic 1997b). Such analysis would show that the strength and the legitimacy of the former rulers in Yugoslavia, and in Serbia likewise, were less eroded at the end of the eighties than in the other former "socialist" countries. Therefore, their persuasive (and manipulative) power was greater than in other countries. Secondly, the "self-management ownership arrangements", in spite of all evident discrepancies between the "project" and the reality of self-management, generated greater employee identification with their normative role of "co-owner" and led to greater inclinations of the majority of employees toward some forms of "employee ownership" as a form of privatization and not to the "voucher" type of privatization of former state firms practiced in some other post-socialist countries. ${ }^{7}$

Under such societal conditions a peculiar "vicious circle" of the blocked transition in Serbia was established (Bolcic 1997a), where the existing power system prevented immediate full-scale privatization of state/social property, while the prolonged life of "social/state property" reinforced the existing power system.

The breaking of this "vicious circle" was slow and socially painful. One of the contributing forces in the removal of blockage from the way of transition in Serbia seems to have been the new entrepreneurs, especially those thousands of small entrepreneurs in all parts of the present-day Serbia.

\section{THE SPREAD OF ENTREPRENEURSHIP IN SERBIA IN THE NINETIES}

Social abnormalities became a distinguishing feature of Serbia at the end of the eighties. In such a social context the continuing spread of private entrepreneurship, the enlargement of the social strata of private entrepreneurs, and the increased entrepreneurial inclinations among all segments of the present Serbian society have come as a surprise.

Objective indications of this spread of entrepreneurship are given in Table 3, on numbers and proportions of private enterprises in the nineties.

Table 3. Private enterprises in Serbia, 1990-1997

\begin{tabular}{lrrrr}
\hline & 1990 & 1991 & 1997 & 2000 \\
\hline No. of private enterprises & 21,567 & 44,780 & 178,432 & 167,555 \\
$\%$ of all private firms & 77 & 81 & 91 & 80 \\
Index $(1990=100)$ & 100 & 208 & 827 & 777 \\
\hline
\end{tabular}

Sources: Zec et al. 1994; SGJ-95; SGJ-98.

6 According to the available survey data (Slavujevic 1997: 67) the army as institution was the most trusted of all institutions of the state in Serbia, even after its "debacles" in the "Yugoslav" wars since 1991.

7 In a survey done in 1992 orientation toward workers' ownership was more frequent (33\%) than toward the "sale" of "social"/state capital (29\%), see Vukovic 1996; the same orientation has been registered in Slovenia (see Kanjuo-Mrcela 1994: 109.) 
Since private enterprises did not exist before 1989 and official statistics started to publish data on them in 1990, indications presented in Table 3 depict a "great leap forward" in respect of the spread of entrepreneurship in Serbia during the nineties. The number of these private enterprises at the end of the nineties was some eight times bigger than at the beginning of the nineties. ${ }^{8}$

It is known that as much as $80 \%$ of all private firms were (and still are) very small, with less than 5 employees (Popovic 1995: 53). Therefore, this nine-tenth of all private firms provided employment for some $14 \%$ only of the total employment in Serbia in the year 2000. But, if we add individuals engaged in private farming (and they were not registered as "employed" persons in statistical sources), then, self-employed individuals in private handicraft shops and also all those unregistered individuals in "informal enterprises" working in the sector of the hidden economy, the share of the active population of Serbia, directly depending on private enterprise may be estimated to be up to one-third of the total active population. This has been an expanding segment of the Serbian society in the nineties ${ }^{9}$ whose overall social impact was even greater than reflected by the presented quantitative measure of its importance. The new owners and entrepreneurs were establishing a new life orientation and new rules for the rest of the society.

The expansiveness of the social impact of entrepreneurs comes in part from their basic societal role as promoters of innovations in business life, as "risk-takers" who are ready to act according to their own judgments, often away from, and even against conventional routes. It seems that the existing increasing de-structuring ("destruction" "10) of the Serbian society, with a lot of disorganization, has not discouraged most of the small entrepreneurs to continue to do private business, even if it assumed frequent changes of their specific field of business.

\section{THE MAIN FEATURES OF NEW ENTREPRENEURS}

There are controversies about the features and future role of the rapidly growing social group of new entrepreneurs in Serbia, as in other countries in transition. Many social actors (political parties and other groups) in the public arena are now strongly "lobbying" for entrepreneurs. Entrepreneurs are being pictured as promoters of a truly modern and efficient business, which should restore a sound and modern market economy in these former socialist societies. On the other side of the public scene there are commentators of recent social changes in Serbia who blame new entrepreneurs for the spread of undesirable consequences of recent transitory changes (like, the revival

8 The variations in indices for various years might be describing the reality, but also could be in part due to unreliable statistical data, and, the fact that, especially at the beginning of the nineties, there were many registered firms not being active in the business life of Serbia.

9 Between 1950 and 1990 the percentage of employed persons in the private "shops" was stagnant (around $2 \%$ ). During the nineties the number of self-employed individuals grew to 190.000 (Minjevic, 1999).

10 I suggested to describe the social situation of Serbia in the nineties as a "destruction of the society", not just the destruction of the former state of Yugoslavia. On features of such a destruction of the fundamentals of the society see Bolcic 1994: 141-147.

Review of Sociology 9 (2003) 
of many aspects of the "primary accumulation" of capital, of the proliferation of various forms of illegal, "Mafia" business practices, etc.). These conflicting assessments seem to work against the strengthening of the positive attitude of the general public in Serbia toward entrepreneurs and entrepreneurship and also affect state measures aimed at the societal regulation of entrepreneurship.

Part of these controversies derives from the discrepancy of the real features of new entrepreneurs and their expected characteristics. So, it was expected that entrepreneurs in these societies in transition should be mostly new people who would come outside of the former nomenclature, outside of circles of former socialist managers, even outside of circles of employed persons in the former social/state sector. They were expected to be individuals with considerable work experience in private business, those who worked in entrepreneurial firms in Western capitalist countries, individuals with considerable family traditions in private business, and also persons with appropriate knowledge ("know-how") needed in modern business. Do new entrepreneurs in Serbia meet these expectations, or who are they, in fact?

According to the available 1992 survey data ${ }^{11}$ it may be said that $59 \%$ of the new private entrepreneurs were employed in "social firms" before they became private entrepreneurs; some $2 \%$ of them were previously employed in foreign firms in Yugoslavia and $6 \%$ of them were employed abroad; $4 \%$ were self-employed or employed in other private firms; $25 \%$ of them were unemployed persons. So, in $85 \%$ of cases the new entrepreneurs in Serbia have come either from the circle of employees in "social firms" or from the circle of unemployed persons.

New entrepreneurs in Serbia are people of various basic occupations and work roles (in an open question respondents have mentioned some 50 different work roles that they had before becoming private entrepreneurs). Very frequently (in $36 \%$ of the cases) they were in some leading (managerial) positions in organizations (heads of divisions, departments, sectors, including general managers.). Relatively frequently (in 14\% of cases) they were personnel of financial, commercial and similar divisions of firms; in $11 \%$ of cases they were in professional jobs. Some $16 \%$ of them were in positions of ordinary workers, but most of these workers were workers in trade and services.

This frequent take-over of the entrepreneurial positions by the former socialist managers, observed also in other societies in transition (Lengyel et al. 1992), is even more evident in somewhat bigger private firms, those of 30 employees or more. In this case $47 \%$ of private entrepreneurs were in managerial positions (Lazic et al. 1994). These individuals had access to various social networks, which seem to be very relevant for their business activities (see Lengyel et al. 1992: 135).

When considering the prevalent age of new entrepreneurs one could assume that their younger age had been probably of the greatest importance for their decision to become entrepreneurs and also for their frequent success in the new occupational role

11 The 1992 survey provided data on 373 private entrepreneurs (owners, owners with managerial role and managers of various private firms); see details on methodology in the "Methodological Note" at the end of this paper and in Bolcic 1995c. Unfortunately, there are no comparable data for recent years, except for some of characteristics of "private owners", based on recent surveys of this author. Official statistics in Serbia are not providing data on characteristics of entrepreneurs. 
since they were individuals with great ability to learn "new things". According to our 1992 survey data, $47 \%$ of the surveyed entrepreneurs were younger persons (of less than 35 years of age) and only $15 \%$ of them were older than 45 years of age. The data from the 1994 and 1999 surveys confirm this finding and allow the comparison of the age structure of owners of firms, other employees of private firms and employees of "social firms". As it can be seen in Table 4, both private entrepreneurs and employees of private firms in the present Serbia are younger than employees in "social firms". One may assume that these younger employees in private firms come either from among those who had been previously unemployed and also from the circle of employees in "social firms".

Table 4. The age characteristics of various social segments of Serbia,1994-1999

\begin{tabular}{|c|c|c|c|c|c|c|c|c|}
\hline \multirow[t]{2}{*}{ Age group } & \multicolumn{2}{|c|}{ Owners of firms } & \multicolumn{2}{|c|}{$\begin{array}{l}\text { Employees in } \\
\text { private firms }\end{array}$} & \multicolumn{2}{|c|}{$\begin{array}{c}\text { Employees in } \\
\text { social firms }\end{array}$} & \multicolumn{2}{|c|}{$\begin{array}{c}\text { All } \\
\text { respondents* }\end{array}$} \\
\hline & 1994 & 1999 & 1994 & 1999 & 1994 & 1999 & 1994 & 1999 \\
\hline $21-30$ & 19.6 & 37.8 & 41.0 & 36.8 & 11.5 & 17.2 & 22.3 & 27.0 \\
\hline $31-40$ & 39.1 & 15.6 & 19.7 & 25.4 & 25.6 & 25.9 & 15.1 & 16.3 \\
\hline $41-50$ & 30.4 & 31.1 & 26.2 & 21.9 & 39.0 & 37.4 & 25.2 & 21.0 \\
\hline $51-$ & 10.9 & 26.7 & 9.8 & 11.4 & 22.6 & 19.0 & 37.4 & 30.3 \\
\hline Total & 100 & 100 & 100 & 100 & 100 & 100 & 100 & 100 \\
\hline Number & 46 & 45 & 61 & 114 & 305 & 348 & 766 & 1128 \\
\hline
\end{tabular}

* In the 1994 survey respondents were from the "Belgrade region", including municipalities outside the Belgrade City limits. In spite of some differences, in "structural" sense these data are comparable to the 1999 survey data.

It is clear that even if there are differences between the first and second half of the nineties in age characteristics of the social segments compared, the basic trend of having younger people in private firms and older people in "social" firms has not changed during this decade. In the 1999 there were more young owners of private firms of the age 21-30, who must have entered the "entrepreneurial circle" in the second half of the nineties. Also, there are more private owners in the age group of 50 years and more. These "older" entrepreneurs should be those who were younger (41-50) at the beginning of the nineties and who have succeeded in "surviving" as entrepreneurs in those turbulent years of the nineties in Serbia.

The movements of the work force from the "social" to private firms in the nineties in Serbia meant not only a "draining" of younger employees but also an overall "draining" of skilled persons from "social firms". Those skilled people who left "social firms" and got employment in private firms in many cases were not individuals with greater formal education, as it is documented in Table 5 on the education of owners of firms in 1994 and 1999. 
Table 5. Education of owners of private firms: Serbia, 1994-1999

\begin{tabular}{lccccccc}
\hline & $\begin{array}{c}\text { Less than } \\
\text { second. } \\
\text { school }\end{array}$ & $\begin{array}{c}\text { Secondary } \\
\text { school }\end{array}$ & $\begin{array}{c}\text { Higher } \\
\text { education }\end{array}$ & University & \multicolumn{2}{c}{ All respondents } \\
\cline { 6 - 8 } & 18 & 66 & 7 & 9 & 100 & number* \\
\hline Belgrade, 1994 & 7 & 69 & 13 & 11 & 100 & 44 \\
Serbia, 1999 & 7 & & & & &
\end{tabular}

* The small number of owners of private firms is hampering interpretation. Since these data come from the survey of randomly selected inhabitants of 18 years and over, the number of this subgroup was inevitably small. Still, findings on the education of private owners from the quoted surveys are consistent with findings of the special survey of 373 entrepreneurs in 1992 (Bolcic 1994: 106).

Source: Surveys of the Institute for Sociological Research, Faculty of Philosophy, Belgrade.

The prevalence of individuals with secondary education among entrepreneurs and owners of private enterprises is evident. On the other hand, $28 \%$ of a sub-sample of private entrepreneurs running firms of 30 employees and over (Lazic et al. 1994) had secondary school education, $28 \%$ had "higher" education and $44 \%$ were persons with university education. In spite of these variations in the proportion of private entrepreneurs with secondary-level education in these sub-samples, it seems clear that, at this first stage of transition, the new entrepreneurs in Serbia have rarely had university education. In that respect, managers of "social firms" are still better educated than private entrepreneurs (according to the findings of Lazic et al. 1994, $89 \%$ of the managers of "social" firms had university education).

From our 1994 survey in the Belgrade region one could say that from the point of formal education the "quality" of the average personnel in "social firms" was still somewhat better than the one in private firms: while "social firms" had some $18 \%$ of those with university education, in private firms $11 \%$ of employees had this highest level of education.

This peculiar educational profile of the new entrepreneurs in Serbia requires some comments. First, this prevalence of entrepreneurs with secondary-level education seems to be related to the prevalence of very small private firms that were being established in the nineties. According to our 1992 survey, $60 \%$ of firms had no more than 5 employed persons and only $5 \%$ of them had 30 employed persons and more. ${ }^{12}$

These new private firms are organizations of the "simplest form" (Mintzberg 1983), and it seems normal that the entrepreneurs (owners and managers) do not need the highest, university education. This is even more natural when we take into account the prevalent activities of these private firms. In the 1992 survey $45 \%$ of the surveyed firms were in trade, $20 \%$ in traditional (personal, artisan's) services and in the restaurant business, $21 \%$ in other, modern services, like health, recreational, professional, financial and similar services. Only $14 \%$ of these firms were active in industrial production, construction and productive handicraft. A similar profile of business activities of private firms could be documented with official statistical data (see SGJ-01: 54), and also by our survey in the Belgrade region, in April 1994. One

12 According to the official statistical data for the year 2000 (SGJ-01:54) private enterprises had 4 employees in the average. 
could assume that the actual technology of trading in such small firms requires knowledge and skills sufficiently provided by secondary schools. Also, persons of such education seem to find their "trade-offs" more easily (what they gain and what they lose) when changing their former occupation than persons with university-level education. But, individuals with university education will be more often found in modern services, especially in professional (intellectual) ones.

The described educational profile of new entrepreneurs seems to be related to their business practices (for example, their strategy of doing any business which seems to be profitable even in the shortest run) and also to their "social activities" (like, frequent participation in various celebrations, shows, where they show their "riches"). But this "style" of life of the "new entrepreneurs" should be more thoroughly studied. One could say that the prevalent secondary-level of education of the new entrepreneurs also affects the actual public perceptions and assessments of this new economic elite. The sudden social promotion of new entrepreneurs to an elite position is not readily accepted as legitimate by ordinary people. Their success can hardly be explained by their greater knowledge, talents, and innovative capacity. The entrepreneurs in our 1992 survey related their success in business in $28 \%$ to their knowledge, in $17 \%$ to good connections with the "powerful" in government. In $14 \%$ of the replies they mentioned speedy reactions to market demands, in $13 \%$ they stressed the originality of their ideas, in $8 \%$ they mentioned the hard work of their employees, $4 \%$ mentioned luck, some $6 \%$ pointed at the relevance of the branch in which one was doing business, or state regulations, and $3 \%$ gave other replies. ${ }^{13}$

Entrepreneur's knowledge is, evidently, the most frequently pointed quality of successful businessmen (entrepreneurs) in the present Serbia. It is interesting, however, that both potential (in the 1991 survey) and actual entrepreneurs (in the 1992 survey) stressed good connections with "the powerful in government" as the second most important circumstance for the success of entrepreneurs.

It is important to note that new entrepreneurs in Serbia are newcomers from the point of their family background and in relation to the entrepreneurial experiences in their families. In the 1992 survey the occupation of the parents of our entrepreneurs was as follows: peasants (14\%); private artisans (7\%); unskilled and semi-skilled workers $(24 \%)$; qualified and highly qualified workers $(5 \%)$; workers in services (9\%); clerks (7\%); "technicians" (with secondary-level education) (2\%); professionals (14\%); military persons (4\%), other occupations (10\%). One could assume that some of those professionals were also in managerial position even though respondents had not given this answer in an open question.

In comparison to the active population in Serbia, at least one-third of which is still in peasant occupations, our new entrepreneurs are much less of peasant family background and also quite rarely they are the offspring of private artisans. They come evidently more often from families of non-agricultural "working people" of various occupations and education. This picture of the social mobility of new entrepreneurs is

13 Respondents could select and rank two "conditions" of success. Here data of the condition selected as the first one are given.

Review of Sociology 9 (2003) 
somewhat different for the sub-sample of bigger entrepreneurs (Lazic 1994), whose fathers were considerably more often, or still are, managers.

It is relevant also to consider the existence of some family tradition in entrepreneurship as a contributing element to the formation of new entrepreneurs. In our 1992 survey respondents were asked: "Was there or is there someone in your family or of your closest relatives in the private business?" Their replies were as follows:

- was and is now in private business (21\%)

- was but is not in private business now (12\%)

- was not before, but is now in private business $(11 \%)$

- was not and it is not now in private business $(56 \%)$.

So, it is evident that the majority of our new entrepreneurs in Serbia are "newcomers", without previous family inclination to entrepreneurship. Still, there is one-third of them with a "family surrounding" that could have fostered their entrepreneurial inclination and one could expect some positive transfer of entrepreneurial experiences and skills to new entrepreneurs. In the 1994 survey in the Belgrade region respondents were asked whether their partners or grandparents were entrepreneurs. Only $17 \%$ of them said "yes", but owners of firms answered "yes" in $33 \%$ of the cases, a result that is similar to the one in our 1992 survey. ${ }^{14}$

The previous characterization of new entrepreneurs in Serbia has pointed out their socio-demographic features. In the most classical and contemporary descriptions of entrepreneurs various social and psychological traits of entrepreneurs are highlighted. Their activity and their success are related to certain social circumstances (like, the openness of social structure, characteristics of the system of social promotion, ownership relations, stability of legal rules, mode of the regulation of the economy, etc.), or to their personal traits (self-confidence, readiness to take risky decisions, etc.). One of the characteristics of the everyday life of entrepreneurs, their frequent communications with different individuals, their intensive social life, their participation in many gatherings were not mentioned too often. This feature of "new entrepreneurs" is now being more often mentioned and studied (see Sociological Abstracts... 1994: 153, 290, 304). Evidently, this intensive social life of entrepreneurs seems to be important for their entrepreneurial activities. They get relevant information and quite often initial support to their intended business activities from others.

This assumption on the greater sociability of entrepreneurs as one of their relevant features could be, at least tentatively, supported by our survey data. In the 1992 survey respondents were asked: "How many good acquaintances with whom you have frequent contacts do you have?" Two-thirds of the surveyed entrepreneurs were included in "larger circles" (of 20 persons and more) and even $43 \%$ of them were encircled by groups of 40 persons and more. In comparison, the potential entrepreneurs (in 1991 survey) were encircled only in $11 \%$ of the cases in these large circles of 40 persons and more.

14 Almost the same results came from our 1999 survey: see Bolcic 2002: 116.

Review of Sociology 9 (2003) 
In the 1994 survey respondents were asked: "How many friends do you have?" Their answers are reported in Table 6. Variations in the size of the circles of friends are not great, but it is evident that owners of firms do have a greater number of friends, and this could be an indication of their participation in other larger social circles.

Table 6. The size of circles of friends for various categories of the Belgrade population, 1994

\begin{tabular}{lcccccccc}
\hline & \multicolumn{7}{c}{ How many friends do you have? } \\
\cline { 2 - 8 } Category & None & $1-5$ & $6-10$ & $11-20$ & $21-$ & Other & \multicolumn{2}{c}{ All respondents } \\
\hline $\begin{array}{l}\text { All respondents } \\
\begin{array}{l}\text { Employees in social } \\
\text { firms }\end{array}\end{array}$ & 2.9 & 25.3 & 23.7 & 15.3 & 15.9 & 16.9 & 100.0 & 767 \\
$\begin{array}{l}\text { Employees in } \\
\text { private firms }\end{array}$ & 1.3 & 23.2 & 22.9 & 15.7 & 18.0 & 19.0 & 100.0 & 306 \\
Owners of firm & 3.3 & 16.4 & 32.8 & 13.1 & 19.7 & 14.7 & 100.0 & 61 \\
\hline
\end{tabular}

Of course, new and methodologically more appropriate studies of the role of "networking" of entrepreneurs are needed for the assessment of this aspect of their activity and of their successfulness.

One would also need a more in-depth study of the personality of these new entrepreneurs. After all, entrepreneurs are in many respects "peculiar persons" (DeBono 1986) and every entrepreneur would have some peculiar personal "story" (or "secret") about his/her entering in the "world of entrepreneurship" and about his/her path to the success in business (DeBono 1986; Zolak et al. 1991). From our surveys only some tentative observations on these personality traits of the new entrepreneurs in Serbia are possible. When our entrepreneurs in the 1992 survey were asked to select a personal trait which they would consider to be the most important for them as being businessmen, they described themselves as: a hard-working person (24\%); a determined person (21\%); a self-confident person (10\%); a creative person $(8 \%)$; a person capable to find his own way $(7.5 \%)$; a person devoted to some idea $(6 \%)$; a person ready to accept risk (5\%); a person being easy in contacting others $(5 \%)$; a person with "good nerves" (3.5\%); an optimistic person (3\%).

It was no surprise to get such a variety of descriptions of personal traits of new entrepreneurs. From the textbook notions on entrepreneurs one might have expected greater stress on creativity ("innovativeness") and on the acceptance of risks. One might say, however, that under the actual, very unstable social conditions in Serbia, those new entrepreneurs seem to accept risks more than it is expressed by these survey data. Also, there must be some peculiar creativity (innovativeness) in their everyday activities to maintain the actual level of normalcy in economic life in Serbia, under the chaotic social conditions caused by the decay of the former state of Yugoslavia, by the ongoing "internal war" in the "Yugoslav area" and by the UN sanctions against the "new Yugoslavia". But, according to their direct answers some other personal features seem to be of greater importance: hard work, determination, self-confidence. This 
great stress on hard work might reflect yesterday's socialist or traditional "work ethics", but it could also be a hidden way of legitimating the quick and immense economic success of many new entrepreneurs who have become rich under the conditions of the extreme economic downfall of Serbia in the last several years. Media stories and personal experiences about some of the richest and often controversial new entrepreneurs have certainly contributed to the widespread public perceptions of new entrepreneurs as the main beneficiaries of this transition from socialism, even though many of the small new entrepreneurs have had similar existential problems as other citizens of Serbia.

If we know that the majority (some 70\%) of entrepreneurs were persons in younger and middle age (up to 50 years) and that even $50 \%$ of them were under 40 years of age, then this social expansiveness of entrepreneurs is even more understandable.

The limiting factors of the greater societal role of entrepreneurs, besides those factors related to the overall social situation in Serbia in the nineties, seem to be their over-concentration in the retail business ${ }^{15}$ (some $70 \%$ of private firms are in retail trade and wholesale trade and services). Also, entrepreneurs have, as stated, a relatively inferior education (some $70 \%$ of them have no more than secondary-level education). The relatively inferior education of most entrepreneurs makes them less professionally competent in finding proper business solutions, even in acquiring the needed professional advice from those already employed in their firms or from independent professionals. De-professionalisation seems also to be a relatively frequent case. Around one-third of persons in entrepreneurial roles in private firms worked outside their professions, according to a survey of Vojin (1995). In times when successes in the business in the present world heavily depend on advantages in "know-how", on professional capacities, such undereducated entrepreneurs must be in serious disadvantage when dealing with foreign entrepreneurs, and also in communication with their often better educated employees.

It is often claimed that power-holders in post-socialist societies succeeded to establish a new "ruling coalition" (instead of the former coalition of the politocracy and workers) with new entrepreneurs, especially those controlling larger and strategic companies. This seems to derive from the fact that many of the new entrepreneurs were part of the former "nomenclature cadres", in person or by their family's ties (Mateju 1995) This observation is pertinent also for the Serbian entrepreneurs in the nineties, but mainly for the "bigger" entrepreneurs (Lazic 1996), and not for the thousands of smaller entrepreneurs (Bolcic 1994: 107). In other words, the social origin of small entrepreneurs is quite heterogeneous. Many of them were workers, particularly in trade, and also a significant proportion of entrepreneurs were unemployed persons of various basic occupations. Therefore, important segments of the entrepreneurs should have been socially closer to the deprived strata of society, than to those in power. But, their heterogeneity seems to be one of the reasons of weak association among entrepreneurs and their inferior role as social actors of the transformation of Serbia in the nineties.

15 This tendency of over-concentration of entrepreneurs in retail business should be related, in part, to the lack of capital, but also to the many unoccupied "niches" (and unmet consumers' needs) in the formerly established retail trade during the years of "socialist economy" in this country. 


\section{INCREASING ENTREPRENEURIAL INCLINATIONS}

Among the new forces generating important changes it is not only the new entrepreneurs, but also potential entrepreneurs, individuals from different social strata and occupations with entrepreneurial inclination that have a role. Their number was somewhat greater at the end than at the beginning of the nineties.

Relatively frequent entrepreneurial inclinations in the population of a given country seem to be a good socio-psychological indication of the readiness of a given society to evolve towards an entrepreneurial society. ${ }^{16}$ By virtue of having entrepreneurial inclinations, these people are likely to be supporters of entrepreneurial behaviour in others in a given society.

There are survey data (Table 7) on the increasing entrepreneurial inclinations in the Serbian population in the nineties.

Table 7. Entrepreneurial inclinations of the Serbian population, 1991-1999

\begin{tabular}{lccccc}
\hline & \multicolumn{5}{c}{ Would you like to be a private entrepreneur?* } \\
\cline { 2 - 6 } & Yes & It depends & No & $\%$ & $\begin{array}{c}\text { Number of } \\
\text { respondents }\end{array}$ \\
\hline Serbia (1991) & 20 & 41 & 39 & 100 & 1015 \\
Belgrade (1994)** & 17 & 33 & 50 & 100 & 800 \\
Serbia (1998) & 25 & 25 & 50 & 100 & 1247 \\
Serbia (1999) & 22 & 38 & 40 & 100 & 1123 \\
\hline
\end{tabular}

*This was not the exact wording of the question of the 1991 survey, but in substance this was the meaning; see for details Bolcic 1998: 10-11.

** Data for Belgrade are for the whole Belgrade region and could be considered as a good approximation for Serbia.

Sources: Surveys of 1991, 1994, 1999, by the Institute of Sociology, Faculty of Philosophy, and the 1998 survey by the Institute of Social Sciences, Belgrade.

The proportion of respondents with "determined" entrepreneurial inclination ("yes" answer) in 1994 was somewhat lower than in 1991. ${ }^{17}$ It might reflect some discouraging experiences of entrepreneurs during the 1991-1993 period. It was a period of "hyper-hyper inflation", of tragic wars in the Yugoslav region, therefore a period of very risky business for most entrepreneurs. Decreasing entrepreneurial inclinations after the first enthusiasm were found in some other countries, like Hungary (Lengyel 1994), too.

The increased proportion of "determined" potential entrepreneurs (those who said "yes", they would like to entrepreneurs) in Serbia in 1998 when considering all

16 An elaborated concept of a modern "entrepreneurial society" is given in Bolcic 1995c.

17 The proportion of those who do not wish to become entrepreneurs in Serbia seem to be smaller than in some other post-socialist societies (see Lengyel and Kutzi 1995: 158). This deserves further explanation. One might suspect that the experience with self-management, where employees in nominally "social" firms had considerable influence on decisions of these firms, could have contributed to this preference of employment in non-private firms by respondents in Serbia. Of course, other elements should also be considered as relevant.

Review of Sociology 9 (2003) 
unfavorable circumstances for the private business in Serbia, corroborated the thesis of the spread of entrepreneurship in this country in spite of blocked transition. Having experienced a very difficult situation in the first half of 1999, with and after bombing by NATO, it was normal that in the autumn of 1999, when the survey was carried out, there was a slight decrease of "determined" potential entrepreneurs. Of course, because of the decreasing chances for employment at the end of the nineties (some $40 \%$ of the labor force was de facto unemployed in the first half of 1999) inclinations toward some form of self-employment, including the form of private entrepreneurship, were realistic, not necessarily most desired orientations of many individuals in Serbia. But, one has to have a specific self-confidence and "drive" to select such a path in life, especially in a society where entrepreneurship in business has not been particularly socially supported, and not only in the years of "socialist construction", but also in the previous periods of Serbian modernization.

Entrepreneurial inclinations in Serbia, as in other post-socialist countries, were most frequent among the young generation (up to 30 years of age) and among the better-educated segments of society (of secondary and higher levels of education). It should mean that the most valuable segments of the actual and potential labor force are open to the dynamism of the modern market economy and to individuals' actions in providing the means for one's life. So, the increased entrepreneurial inclinations in Serbia at the end of the nineties could be regarded as a positive trend. However, the proportion (40\%) of those who rejected the idea of being entrepreneurs should not be forgotten. This is a warning that people still think of secure employment, to which they were habituated in the pre-transition "socialist" times, as a proper way of meeting their existential needs.

As it is shown in Table 8, in $199966 \%$ of the potential entrepreneurs were also potential emigrants (those thinking to go abroad in the near future).

Table 8. Potential emigrants*, Serbia, 1994-1999

\begin{tabular}{lcc}
\hline Segments & 1994 & 1999 \\
\hline Age 21-30 (\%) & 68 & 46 \\
Higher education (\%) & 34 & 49 \\
Potential entrepreneurs (\%) & 43 & 66 \\
\hline
\end{tabular}

* Potential emigrants were those who answered that they "think to go abroad for long". Sources: Surveys of ISFF in 1994 and 1999, organized by the author.

The proportion of potential emigrants among persons with higher education and especially among those with entrepreneurial inclinations has considerably increased by the end of the nineties. ${ }^{18}$ This indicates the continuing aggravation of the employment possibilities for educated people in Serbia, caused by the persistent reduction of all economic activities in the country in that period. It also reflects the unsupportive social environment for private entrepreneurship under the actual

18 See the data on "potential emigrants" in Bolcic 1995: 94-104. 
conditions of suppressed transition, voluntaristic changes in the ownership relations, and under a long-standing aversion toward entrepreneurs in this country.

In the early years of transition in Serbia (1990-1991) the most often mentioned "big entrepreneurs" (glorified by the media) turned quickly to be "crooks" whose abilities in making money were not in business innovation but in making false promises (in the form of promised very high interest rates per month on deposited money in their "banks", saving agencies, sales companies, etc.). ${ }^{19}$ It was not a surprise that public perceptions of the new entrepreneurs were often negatively pictured in the early nineties. Yet, in spite of such unsupportive social perceptions at the beginning of the period of transition, entrepreneurial inclinations continued to increase. The majority of the impoverished Serbian population ${ }^{20}$ may still envy all those who have had a different life in those years of the collapse of the Serbian economy, including entrepreneurs whose living conditions were, in the average, better than that of the rest of the population. One could assume that ordinary people perceived many advantages of private entrepreneurship for the society's well being. They understood that over-all poverty in Serbia in these "lean years" would have been more severe if there were no private entrepreneurs.

Individuals with entrepreneurial inclinations, after observing the "Serbian realities" have not abandoned their entrepreneurial "dreams". But many of them were thinking and dreaming to emigrate with hopes to have better chances for work and life "somewhere away from Serbia". This form of dissatisfaction of entrepreneurs, actual and potential, with the present situation could have led not only to real emigration, but also to some increased social pressures for more radical changes in Serbia which would meet the interests of all social strata, including the interests of entrepreneurs. So, entrepreneurship (actual and potential) seems to have generated positive social pressures and led toward the transformation of Serbia even under the condition of suppressed transition and in a relatively unsupportive socio-cultural "climate".

\section{ON THE IMPACT AND PROSPECTS OF ENTREPRENEURSHIP IN SERBIA}

Since1989 private entrepreneurs in Serbia established their firms in the trade business (wholesale and retail trade) in some $65 \%$ of the cases, preventing the dramatic decrease of the population's consumption, which would have followed the steep fall of the domestic production since 1990.

From official statistics (SGJ-01) it is found that in 1990-1999 the total turnover in trade (in constant 1994 prices) dropped less than was the fall of the GDP in the same period. So, while the turnover in retail trade was $65 \%$ of the 1990 turnover in 1999 , the GDP in 1999 was $44 \%$ of the GDP in 1990.

Thanks to thousands of private entrepreneurs, in spite of international sanctions since 1992, some import - export activities continued to exist and people in Serbia in

19 Some observations, based on the analyses of the press, are given in Bolcic 1994: 134.

20 According to Posarac's findings, the percentage of impoverished population (those below the "poverty line" in Serbia grew from 6.2\% in 1990 to $35.6 \%$ in 1994 (Posarac 1995: 338).

Review of Sociology 9 (2003) 
the years of the collapse of their economy were still able to buy thousands of "necessities" (like toilet paper, detergents, parts for their cars, appliances...) and it made their life less miserable. Data in Table 9 illustrate this increasing role of entrepreneurship in the private trade since 1990.

Table 9. The growth of private trade, Yugoslavia*, 1990-1999

\begin{tabular}{lrrrr}
\hline & 1990 & 1992 & 1994 & $1999 * *$ \\
\hline $\begin{array}{l}\text { Total turnover in retail trade } \\
(000 \text { din)*** }\end{array}$ & 7957 & 5130 & 5131 & 8507 \\
$\begin{array}{l}\text { Turnover in private retail trade } \\
(000 \text { din })\end{array}$ & 1084 & 2268 & 4086 & 4364 \\
$\%$ of private in total r. trade & 14 & 44 & 80 & 51 \\
$\begin{array}{l}\text { Employed persons in total } \\
\text { retail trade }\end{array}$ & 107,316 & 122,937 & 140,258 & 100,567 \\
$\begin{array}{l}\text { Employed in private retail trade } \\
\% \text { of private in total employment }\end{array}$ & 13,434 & 33,360 & 77,165 & 83,414 \\
\end{tabular}

* Available data for Yugoslavia describe well the situation of Serbia too.

** Without data for Kosovo.

*** Turnover is given in millions of 1994 Yugoslav Dinars and in 1994 constant prices. Source: SGJ-98.

The turnover of the private retail trade firms grew rapidly and in 1999 it was some $51 \%$ of the total turnover of retail trade. In 1994 the percentage of the turnover of private retail trade was as much as $80 \%$, reflecting the total collapse of retail trade of "social" trading firms in the previous period of hyperinflation. Private retail trading firms were also employing an increasing proportion of the total employment in retail trade (55\% in 1994 and $83 \%$ in 1999), contributing to the alleviation of increasing unemployment in this country in the given period. One could speculate ${ }^{21}$ about the possible increases in private employment if in other fields of private business there were equal conditions for the increase of business activities, especially in productive branches, as was the case in the retail trade business.

Data on this de facto privatization of the retail trade branch of the Serbian economy under the condition of the still missing privatization of major retail trade firms in social ("public") ownership is one of the proofs of the thesis of this paper that in spite of blocked transition some post-socialist transformations in Serbia had been taking place in the nineties.

From a long-term perspective learning another way of life, less depending on the state's concerns, might be the most beneficial consequence of the spread of entrepreneurship in Serbia in the nineties. It was learning new obligations and rights by those who have employed themselves by establishing a private firm and learning by

21 Unfortunately, official statistics is not providing similar data for other branches as those for the retail trade branch. 
ordinary people as well. They became customers of such private firms, now existing and doing business in practically all branches (not just in farming, handicraft and some services, like in the pre-transition period). It was learning for those in power since their power has diminished under the conditions of growing private entrepreneurship.

Entrepreneurs were growing in numbers and as economic actors under the conditions not favorable for entrepreneurship, and it was due to their readiness to use their personal and family capital (including, of course, also their "social capital") for private business under quite risky conditions for any business.

Strangely enough, while the actual regime did little for the spread of entrepreneurship in Serbia, entrepreneurs indirectly helped in some degree the regime's survival, particularly by lessening the pauperization of most of the Serbian population and by postponing the uncontrollable social unrest of generally greatly dissatisfied people.

\section{LESSONS FROM SERBIAN “DEVELOPMENTS” IN THE NINETIES}

It has been usual in the recent years to forget and ignore Serbia in reviews of transition processes in East-Central Europe. Yet, it is unwise to forget Serbia when analyzing the post-socialist transformations in East-Central Europe. Serbia is an interesting case of social transformation in spite of the suppressed and greatly blocked transition, as was partly documented in this paper. There are several lessons to be considered from Serbian "developments" in the nineties:

1. The transformation forces and actors in post-socialist societies are various and in that respect the entrepreneurs are of particular importance. ${ }^{22}$

2. The very reappearance of entrepreneurs and of the owner's strata in Serbia should be considered as an event of change of a deep and positive impact on the given society.

3. Entrepreneurs have been expansive social actors, with great self-generating developmental power, whose presence and activity enlarged the social space of the free actions of others in the society as a whole, even under very unfavorable social conditions.

4. The prerequisites for the reappearance and expansion of entrepreneurs seem to be relatively simple: the legalization of the free formation of enterprises (firms), irrespective of their legal ownership status, and the restitution of full management prerogatives of founders of firms. ${ }^{23}$ All other institutional and real social, economic, political, cultural and other circumstances related to the spread of entrepreneurship are

22 Entrepreneurs are individuals and other social actors performing entrepreneurial role (introducing and realizing business innovations, taking risky decisions and providing strategic changes in business life). They are not necessarily owners of firms, but they are key actors in forming and directing firms. These firms where entrepreneurs will be found are not only "small firms", but also large companies, in various ownership status. In the author's investigations of entrepreneurs in Serbia, operationally entrepreneurs were owners and managers of non-state firms.

23 These prerequisites for the spread of entrepreneurship in Serbia were provided already in the 1988-1989 "reform laws" of the Ante Markovic government.

Review of Sociology 9 (2003) 
important but not decisive when those basic prerequisites for their reappearance are being met.

5. The positive impact of entrepreneurs is not only in generating systemic transformations but also in everyday real-life transformations. Entrepreneurs prevented a more serious aggravation of the living conditions of people in Serbia as well as in other post-socialist societies, caused by the "implosion" of their former socio-economic systems. In Serbia, because of all of its social disruptions, without thousands of (mostly small) entrepreneurs, the severity of pauperization would have been insupportable.

6. The long-term impact of entrepreneurs as strata on the social transformations of the post-socialist societies should not be judged solely on their actual, still limited economic and political power and on some of their actual "personality" characteristics. They are in principle an expansive social actor, introducing new rules and patterns of behavior (individual initiatives, risk-taking, individual responsibility for one's well-being, generating wealth based on one's work and successfulness in business life), which are congruent with the needs and interests of most members of modern societies. By transforming a former "socialist" society in the direction of an "entrepreneurial society" entrepreneurs are acting as promoters of a modern open society where all individuals have real opportunities to fully use their abilities to their benefit. This trend toward an "entrepreneurial society" existed, though feebly, even in Serbia in the nineties, in spite of its suppressed transition.

\section{REFERENCES}

Bolcic, S. (1992): Cultural Dimension of Entrepreneurship - Some Empirical Findings for the Yugoslav Region, Ekonomska analiza, 2.

Bolcic, S. (1994): Tegobe prelaza u preduzetnicko drustvo. [Hardship of Transition toward the Entrepreneurial Society] Beograd.

Bolcic, S. (1995a): Drustvene promene i svakodnevni zivot: Srbija pocetkom devedesetih. [Social Changes and Everyday Life: Serbia in the Early Nineties] Beograd.

Bolcic, S. (1995b): The Features of a "Nationalised Society" Sociologija, 4., Belgrade.

Bolcic, S. (1995c): The Meaning of the Social System and the Initial Achievements of the 'Post-Socialist' Transition. Balkan Forum, 3, Skopje.

Bolcic, S. (1997a): Ownership Transformation and Problems of Redistribution of the Social Power in the Post-Socialist Societies. Balkan Forum, 2, Skopje.

Bolcic, S. (1997b): Osobenosti kulture interesnog delovanja u Srbiji devedesetih. [Peculiarities of the Culture of the Interest Acting in Serbia in the Nineties] In Vasovic, M. (ed.): Fragmenti politicke kulture, Beograd.

Bolcic, S. (1998): Entrepreneurial Inclinations and New Entrepreneurs in Serbia in the Early Nineties. International Journal of Sociology, 4.

Bolcic, S. ed. (2002): Srbija krajem mileniuma: razaranje drustva, promene i svakodnevni zivot. [Serbia at the End of Millennium: Social Destruction, Changes and Everyday Life] Beograd. Bozovic, G. (1992): Siva ekonomija u Jugoslaviji. [Hidden Economy in Yugoslavia] Beograd. DeBono, E. (1986): Tactics: The Art and Science of Success. London: Fountana Books.

Flamm, H. (1987): The Shaping of Social Organisation. Sage, London. 
Goati, V. ed. (1995): Challenges of Parliamentarism: the Case of Serbia in the Early Nineties. Belgrade.

Goati, V. (1999): Izbori u SR Jugoslaviji od 1990 do 1998. [Elections in FR Yugoslavia from 1990 until 1998] Beograd.

Golubovic, Z., Kuzmanovic, B. and Vasovic, M. (1995): Drustveni karakter $i$ drustvene promene u svetlu nacionalnih sukoba [Social Character and Social Changes in the Light of Ethnic Conflicts] Beograd.

Hagen, E. (1962): On the Theory of Social Change. Homewood, Ill.

Kanjuo-Mrcela, A. (1994): Sindikati i privatizacija. [Trade Unions and Privatization] Druzboslovne rasprave, 17-18, Ljubljana.

Kostic, M. (1994): Uspon Beograda. [The Rise of Belgrade] Beograd.

Lazic, M. et al. (1994): Society in Crisis. Belgrade.

Lazic, M. (1996): Economic Elites in Yugoslavia at the Beginning of the Nineties, In Lengyel, Gy. (ed.): Transformation of the East-European Economic Elites. Budapest.

Lengyel, Gy. (1994): Social Consequences of Transformation: Entrepreneurial Inclinations in Hungary 1988-1993, Budapest.

Lengyel, Gy. (1997): Entrepreneurs and Entrepreneurial Inclinations in Post-Communist East-Central Europe, International Journal of Sociology, 3.

Lengyel, Gy., Offe, C. and Tholen, J. (1992): Economic Institutions, Actors and Attitudes: East-Central Europe in Transition. Budapest.

Lengyel, Gy. and Kutzi, T. eds. (1995): The Spread of Entrepreneurship In Eastern Europe: Survey Evidence on Entrepreneurial Inclination. Budapest: BKTE.

Lim, N. (1995): Who Has Gotten Ahead after the Fall of Communism? Czech Sociological Review, III. 2, Praha.

Marx, K. (1970): Kapital, I. Beograd.

Mateju, P. and Lim, N. (1995): Who Has Gotten Ahead after the Fall of Communism? The case of Czech Republic. Czech Sociological Review, 3.

Minic, J. (1993): Komparativna analiza ekonomskih programa politickih stranaka u SR Jugoslaviji. [Comparative Analysis of Economic Programs of Political Parties in FR Yugoslavia] Sociologija, 1.

Minjevic, D. ed. (1999): Zlatni krug 98. [The Golden Circle 98] Beograd: Beokom.

Mintzberg, H. (1983): The Structuring of Organizations. N. J.: Prentice-Hall.

Molnar, A. (1996): The Collapse of Self-Management and the Rise of Fuhrenprinzip in Serbian Enterprises, Sociologija, 4.

Offe, C. (1992): Capitalism by Democratic Design? Democratic Theory Facing the Triple Transition in East-Central Europe. In Lengyel, Gy. et al. (eds.): Economic Institutions, Actors and Attitudes: East-Central Europe in Transition. Budapest.

Pavlovic, V. ed. (1995): Potisnuto civilno drustvo. [Suppressed Civil Society] Beograd.

Podunavac, M. (1998): Politicka kultura i politicke ustanove. [Political Culture and Political Institutions) In Vasovic, M. (ed.): Fragmenti politicke kulture. Beograd.

Popovic, P. (1995): Preduzetnistvo: granice rasta. [Entrepreneurship: The Limits of Growth] Beograde.

Posarac, A. (1995): Pauperizacija stanovnistva Srbije - jedan od osnovnih uzroka potisnutosti cicilnog drustva. [Pauperization of the Population of Serbia - One of the Main Reasons of the Suppressed Civil Society] In Pavlovic, V. (ed.): Potisnuto civilno drustvo. Beograd.

Sekelj, L. (1995): Yugoslavia - Change Without Transformation. Sociologija, 4.

Sekelj, L. (1998): Three Patterns of Elite Transformation in Eastern Europe. Sociologija, 4.

SGJ-95 (1995): Statistical Yearbook of Yugoslavia for 1995. Belgrade.

SGJ-98 (1998): Statistical Yearbook of Yugoslavia for 1998. Belgrade.

Review of Sociology 9 (2003) 
SGJ-01 (2001): Statistical Yearbook of Yugoslavia for 2001. Belgrade.

Sociological Abstracts...(1994). Bielefeld: Supl., 173: 153, 290, 304.

Sorman, G. (1994): Le Capital, suite et fins. Paris.

Slavujevic, Z. (1997): Kriza poverenja u institucije sistema. [The Crisis of Confidence in system's institutions] In Mihajlovic, S. (ed.): Izmedju osporavanja i podrske. Beograd.

Vieux, P. (1997): Bosna i obnova hegemonije Sjedinjenih drzava. [Bosnia and Revival of US Hegemony] Socioloski pregled. Beograd.

Vojin, A. (1995): Tendencije deprofesionalizacije u uslovima privatnog preduzetnistva. [Trends of Deprofesionalization under Private Entrepreneurship] Diploma thesis, Faculty of Philosophy, Beograd.

Vukovic, S. (1996): Cemu privatizacija. [Why Privatization?] Beograd.

Zec, M., Boslco, M. and Savic, N. (1994): Privatizacija. [Privatization] Beograd.

Zec, M. and Zivkovic, B. (1997): Tranzicija. [Transition] Beograd.

Zolak, T. and Zolak, V. eds. (1991): Kako smo uspjeli? Budva. 